\title{
Socio-Economic Condition of Communities in Resolving Conflicts in the Bukit Tangkiling Conservation Area
}

\author{
Saptawartono ${ }^{1}$, Kumpiady Widen $^{2}$, Hendrik Segah ${ }^{3}$, Yanarita ${ }^{4}$ \\ ${ }^{1}$ Doctoral Program Environmental Sciences, University of Palangka Raya (email: sapta_wartono@pasca.upr.ac.id); \\ ${ }^{2}$ Faculty of Social and Political Sciences, University of Palangka Raya; \\ ${ }^{3}$ Department of Forestry, Faculty of Agriculture, University of Palangka Raya; \\ ${ }^{4}$ Department of Forestry, Faculty of Agriculture, University of Palangka Raya
}

\begin{abstract}
The Bukit Tangkiling Conservation Area has great potential for natural resources, including clean water, honey bees, recreation services, and religious services. There is also potential for split stone, which had been mined by the people from the rock hills in the area. The potential utilization of these natural resources trigger conflicts between interests to maintain the function and existence of conservation areas with the interests of using split stone for the community in order to meet the development needs of the city of Palangka Raya and its surrounding regions, at the cost of damaging the existing area. As an input in managing the conservation area Bukit Tangkiling is well implemented, research is needed on the social and economic conditions of the community's surrounding the area. The research used survey methods and respondents are determined by purposive sampling and simple random sampling, and data analysis was both qualitative and quantitative. The communities around the Bukit Tangkiling conservation area are dominated by productive age (18-56 years), Banturung Village $59.00 \%$ and Tangkiling Village $54.97 \%$. The level of education is relatively low, Banturung Village $72.96 \%$ and Tangkiling Village $73.29 \%$. Having low education, most of the people have difficulty in finding decent work. Aside from that, most people do not understand the function of the forest or the function of the conservation area and tend to be apathetic about the existence of the Bukit Tangkiling conservation area that must be preserved. For some of these poorly educated people, the work of mining rocks is the best alternative to meeting the economic needs of the household. Income obtained from mining rock ranges from 2-4 million IRD per month.
\end{abstract}

Keywords:

conservation area; society; socio-economic

\section{Introduction}

The Bukit Tangkiling conservation area has great natural resource potential to be used to develop and improve the economy of the community around the region. The existence of the Bukit Tangkiling conservation area is based on the Decree of the Minister of Agriculture of the Republic of Indonesia No. 46/Kpts/Um/ 1/1977 dated 25 January 1977, and has an area of 2,594 ha, consisting of 2,061 ha of Nature Reserve and 533 ha of Nature Park.
Because it has considerable natural resource potential with unique aesthetic and ecological values, the Bukit Tangkiling conservation area is currently managed and utilized as a source of: clean water, honey bees, recreation, and religious services. Aside from that, in the area there are rock hills which have the potential for split stone to be used as building materials in order to meet the needs of stone raw materials for development in the city of Palangka Raya and its surrounding area. For some people, rock 
mining is an alternative source of their household livelihood. The management and utilization of these natural resources has the potential to trigger conflicts between the interests of management activities and the use of conservation areas, with other land use activities such as rock mining, which can damage and threaten the area. A wise attitude is needed in managing and utilizing the Bukit Tangkiling conservation area so that all the interests can be met without harming the area, considering the fact that those who feel the consequences directly from the management and utilization of the area are communities around the area. Pramusita and Sarinastiti (2018, p. 23), states that the development of tourism in an area is considered capable of providing positive impacts, such as increasing community income, increasing foreign exchange earnings, increasing employment and business opportunities, increasing regional income, and so on. Tourism is expected to be able to produce a high multiplier effect. The main formula in tourism development is authenticity, the formula can be found in the lifestyle and quality of life of its people.

Ecological and environmental changes in the Bukit Tangkiling conservation area are mostly caused by human activities. The number of land claims from communities in the area, which then uses land for illegal rock mining, plantations, or settlements, results in damaged ecological and environmental conditions as well as other significant changes from previous conditions. Even though the potential of the region as a catchment area and natural tourism object can be directly felt by the use of water from within the area as a source of drinking water and community tourism destinations, the city of Palangka Raya and its surroundings have provided economic benefits to the surrounding community. However, the people's awareness and understanding of conservation still seems to need improvement (BKSDA Kalimantan Tengah, 2017, p. 1). To provide constructive input on the management and utilization of the Bukit Tangkiling conservation area, in order to accommodate all existing interests and to suppress the occurrence of conflict, research activities are needed to obtain data on the social and economic conditions of the communities surrounding the Bukit Tangkilking conservation area.

Solving social problems requires an understanding of the values held by the community and the participation of key community groups in making decisions about forest management. Today, the key to the success for proper forest resource management is determined by its success in solving the socio-economic problems facing a community. Failure in solving these issues will only bring failure to forest management efforts (Simon, 2001 as cited in Senoaji, 2011, p. 3)

\section{Methods}

Research using survey methods with respondents determined by Purposive Sampling and Simple Random Sampling. Data analysis using descriptive qualitative and quantitative descriptive methods. The research location is in Banturung Village and Tangkiling Village, whose administrative areas are the Bukit Tangkiling conservation area. The object of the research is the Profile of Banturung and Tangkiling villages, household conditions around the Bukit Tangkiling conservation area, public perception of the existence of the Bukit Tangkiling conservation area, and the existence of rock mining in the Bukit Tangkiling conservation area.

The collection of village profile data using questionnaires and interviews with authorized officials who are in the offices of the Banturung and Tangkiling Villages, namely the Head of Banturung Village and the Head of Tangkiling Village. Informants were determined using the purposive sampling technique. The data analysis used descriptive qualitative methods.

The data regarding household conditions and community perceptions was obtained by using questionnaires and interviews, with 264 
household heads in Banturung Village and 241 household heads in Tangkiling Villages. The criteria data obtained for household conditions, namely, type of work, age group, population status, education, monthly income, and ownership of mining land. The criteria for the data obtained are for community perception, namely: perception of the forest function, conservation area function, existence of conservation area and existence of stone mining in the conservation area. Respondents were determined by using the probability sampling technique, which provides equal opportunities for each element (member) of the population to be selected as sample members. The number of respondents is set in simple random sampling using the Isaac and Michael formula (Sugiyono, 2017, pp. 123-126). The data analysis used the quantitative descriptive method.

\section{Results}

\section{Profile of Banturung and Tangkiling villages}

The results of the study of the profiles of Banturung and Tangkiling villages resulted in several conditions in Banturung and Tangkiling Kelurahan, namely:

Table 1.

Land Use and Distribution in Banturung and Tangkiling Village

\begin{tabular}{llcccc}
\hline \multirow{2}{*}{ No } & \multirow{2}{*}{ Use } & \multicolumn{2}{c}{ Banturung Village } & \multicolumn{2}{c}{ Tangkiling Village } \\
\cline { 2 - 5 } & Area (ha) & Percentage (\%) & Area (ha) & Percentage (\%) \\
\hline 1. Settlement & 1.750 & 31,01 & 7.864 & 71,34 \\
2. & Plantation & 250 & 4,43 & 400 & 3,63 \\
3. Grave & 1 & 0,02 & 5 & 0,04 \\
4. Yard & 770 & 13,64 & 250 & 2,27 \\
5. Garden & 0,5 & 0,01 & 0,5 & 0,01 \\
6. & 5 & 0.09 & 5 & 0,04 \\
7. & Other public infrastructure & 2.867 & 50,80 & 2.500 & 22,67 \\
\hline \multicolumn{2}{r}{ Total area } & $\mathbf{5 . 6 4 4}$ & $\mathbf{1 0 0 , 0 0}$ & $\mathbf{1 1 . 0 2 4}$ & $\mathbf{1 0 0 , 0 0}$ \\
\hline
\end{tabular}

Source: Profile of Banturung Village, 2016 \& Profile of Tangkiling Village, 2016.

Table 2.

Types of Commodities in Each Leading Sector in Banturung and Tangkiling Villages

\begin{tabular}{|c|c|c|c|c|c|c|}
\hline \multirow[b]{2}{*}{ No } & \multirow[b]{2}{*}{ Mainstay Sector } & \multirow[b]{2}{*}{$\begin{array}{c}\text { Commodity } \\
\text { Type }\end{array}$} & \multicolumn{2}{|c|}{ Banturung Village } & \multicolumn{2}{|c|}{ Tangkiling Village } \\
\hline & & & $\begin{array}{l}\text { Production } \\
\text { Value (IDR) }\end{array}$ & Information & $\begin{array}{l}\text { Production } \\
\text { Value (IDR) } \\
\end{array}$ & Information \\
\hline 1. & Agriculture & Cassava & $24,000,000$ & Area of 1.5 ha & $24,000,000$ & Area of 1.5 ha \\
\hline 2. & Plantation & Rubber & $445,000,000$ & Area of 1.5 ha & $445,000,000$ & Area of 1.5 ha \\
\hline 3. & Ranch & Mixed & $81,000,000$ & 3,450 tails & $250,000,000$ & 7,000 tails \\
\hline 4. & Fishery & Mixed & - & - & $188,000,000$ & 3 types \\
\hline 5. & $\begin{array}{l}\text { Mining and } \\
\text { Excavation }\end{array}$ & $\begin{array}{l}\text { Sand and } \\
\text { Stone }\end{array}$ & $510,000,000$ & - & $59,000,000$ & - \\
\hline
\end{tabular}

Source: Profile Kelurahan Banturung, 2016 E Profile Kelurahan Tangkiling, 2016.

Table 3.

Population in Banturung and Tangkiling villages

\begin{tabular}{|c|c|c|c|c|c|}
\hline \multirow{2}{*}{ No. } & \multirow{2}{*}{ Village } & \multirow{2}{*}{ Number of Family Heads (person) } & \multicolumn{3}{|c|}{ Number of Population (person) } \\
\hline & & & $\operatorname{Man}(\mathrm{M})$ & Woman $(\mathrm{W})$ & Total $\mathbf{M}+\mathbf{W}$ \\
\hline 1. & Banturung & 998 & 2,959 & 2,666 & 5,625 \\
\hline 2. & Tangkiling & 831 & 1,574 & 1,327 & 2,901 \\
\hline & Total & 1,829 & 4,533 & 3,993 & 8,526 \\
\hline
\end{tabular}

Source: Profile of Banturung Village, 2016 \& Profile of Tangkiling Village, 2016. 
1. Land use data in Banturung and Tangkiling sub-districts, as shown in Table 1.

2. Commodity type data from each sector for each village, as shown in Table 2.

3. Population data in Banturung and Tangkiling villages, as shown in Table 3.

4. Population data for Banturung and Tangkiling Villages is based on age, education, occupation, and religious groups, as shown in Table 4.

\section{Household Conditions around the Bukit Tangkiling conservation area}

Research data on the existence and condition of households around the Bukit Tangkiling conservation area can be seen in Table 5 .
Public perception of the existence of the Bukit Tangkiling conservation area and the existence of rock mining in the Bukit Tangkiling conservation area

Research data on the description of the perception of the community surrounding the Bukit Tangkiling conservation area based on the type of work they have can be seen in Table 6 .

\section{Discussion}

Profile of Banturung and Tangkiling villages Banturung village has an area of 5,644 ha and Tangkiling village has an area of 11,024 ha, both of which are administratively located in Bukit Batu Sub-District, Palangka Raya

Table 4.

Population Composition of Banturung and Tangkiling Villages Based on Age, Education, Employment and Religion Groups

\begin{tabular}{|c|c|c|c|c|c|}
\hline \multirow[b]{2}{*}{ No. } & \multirow[b]{2}{*}{ Description } & \multicolumn{2}{|c|}{ Banturung Village } & \multicolumn{2}{|c|}{ Tangkiling Village } \\
\hline & & $\begin{array}{l}\text { Amount } \\
\text { (Person) }\end{array}$ & $\begin{array}{c}\text { Percentage } \\
(\%)\end{array}$ & $\begin{array}{l}\text { Amount } \\
\text { (Person) }\end{array}$ & $\begin{array}{l}\text { Percentage } \\
(\%)\end{array}$ \\
\hline \multirow[t]{4}{*}{1.} & Age group & & & & \\
\hline & a. $0-17$ years & 1,550 & 27.56 & 928 & 31.99 \\
\hline & b. $18-56$ years & 3,319 & 59.00 & 1,595 & 54.97 \\
\hline & c. $\geq 56$ years & 756 & 13.44 & 378 & 13.04 \\
\hline \multirow[t]{9}{*}{2} & Education & & & & \\
\hline & a. Not attending school/No education & pm & pm & 3 & 0.12 \\
\hline & b. Not yet attended school & 511 & 9.08 & 614 & 21.16 \\
\hline & c. Attending school & 1,037 & 18.44 & 298 & 10.26 \\
\hline & d. Not graduated from SD & 250 & 4.44 & 58 & 1.99 \\
\hline & e. Graduated from SD & 1,230 & 21.87 & 557 & 19.20 \\
\hline & f. Graduated from SLTP & 1,076 & 19.13 & 596 & 20.56 \\
\hline & g. Graduated from SLTA & 1,238 & 22.01 & 668 & 23.03 \\
\hline & h. Graduated from PT & 283 & 5.03 & 107 & 3.67 \\
\hline \multirow[t]{8}{*}{3.} & Employment & & & & \\
\hline & a. Farmers/Breeders /Gardens/ Fishermen & 1,221 & 21.71 & 850 & 29.30 \\
\hline & b. Army/Police/PNS & 279 & 4.96 & 188 & 6.48 \\
\hline & c. Retired & 23 & 0.41 & 18 & 0.62 \\
\hline & d. Student & 880 & 15.64 & $\mathrm{pm}$ & pm \\
\hline & e. Not Working & 843 & 14.99 & pm & pm \\
\hline & f. Private/Self Employed & 875 & 15.56 & 573 & 19.75 \\
\hline & g. Others & 1,504 & 26.74 & 1,272 & 43.85 \\
\hline \multirow[t]{7}{*}{4.} & Religion & & & & \\
\hline & a. Islam & 3,715 & 66.04 & 1,409 & 48.57 \\
\hline & b. Christian & 1,707 & 30.35 & 1,085 & 37.40 \\
\hline & c. Catholic & 43 & 0,76 & 53 & 1.83 \\
\hline & d. Hindu & 138 & 2.45 & 309 & 10.65 \\
\hline & e. Buddhist & 6 & 0.11 & 3 & 0.10 \\
\hline & f. Other beliefs & 16 & 0.28 & 42 & 1.45 \\
\hline
\end{tabular}

Source: Profile of Banturung Village, 2016 \& Profile of Tangkiling Village, 2016. 
Table 5.

Data on Household Conditions Around the Bukit Tangkiling Conservation Area

Per Type of Work

\begin{tabular}{|c|c|c|c|c|c|c|c|c|}
\hline \multirow[b]{2}{*}{ No } & \multirow[b]{2}{*}{ Description } & \multicolumn{7}{|c|}{ Type of employment *) } \\
\hline & & $\begin{array}{l}\text { Stone } \\
\text { Miner } \\
\text { (p) }\end{array}$ & $\begin{array}{c}\text { Civil } \\
\text { Servant } \\
\text { (p) }\end{array}$ & Trader(p) & Farmer(p) & $\begin{array}{c}\text { Private } \\
\text { worker } \\
\text { (p) }\end{array}$ & $\begin{array}{l}\text { Services } \\
\text { (p) }\end{array}$ & $\begin{array}{c}\text { Total } \\
\text { (p) }\end{array}$ \\
\hline \multirow[t]{3}{*}{1.} & Number of Family Heads & 37 & 120 & 120 & 78 & 130 & 20 & 505 \\
\hline & a. Banturung Village & 30 & 55 & 32 & 72 & 60 & 15 & 264 \\
\hline & b. Tangkiling Village & 7 & 65 & 88 & 6 & 70 & 5 & 241 \\
\hline \multirow[t]{4}{*}{2.} & Age group & & & & & & & \\
\hline & a. $18 \mathrm{~s} / \mathrm{d} 45$ Year & 20 & 59 & 59 & 37 & 61 & 10 & 246 \\
\hline & b. 46 s/d 56 Year & 7 & 40 & 40 & 21 & 43 & 5 & 156 \\
\hline & c. $>56$ Year & 10 & 21 & 21 & 20 & 26 & 5 & 103 \\
\hline \multirow[t]{4}{*}{3.} & Population status & & & & & & & \\
\hline & a. Native inhabitants & 6 & 68 & 70 & 33 & 62 & 6 & 245 \\
\hline & b. Comers & 28 & 46 & 38 & 43 & 51 & 10 & 216 \\
\hline & c.pm & 3 & 6 & 12 & 2 & 17 & 4 & 44 \\
\hline \multirow[t]{7}{*}{4.} & Education & & & & & & & \\
\hline & a. No education & 2 & 0 & 0 & 2 & 0 & 0 & 4 \\
\hline & b. SD & 9 & 1 & 12 & 15 & 7 & 3 & 47 \\
\hline & c. SLTP & 15 & 0 & 26 & 20 & 10 & 5 & 76 \\
\hline & d. SLTA & 10 & 31 & 69 & 33 & 68 & 10 & 221 \\
\hline & e. PT & 0 & 80 & 3 & 2 & 32 & 0 & 117 \\
\hline & f. pm & 1 & 8 & 10 & 6 & 13 & 2 & 40 \\
\hline \multirow[t]{5}{*}{5.} & Monthly income & & & & & & & \\
\hline & a. Not sure & 7 & 9 & 18 & 26 & 22 & 7 & 89 \\
\hline & b. $<2$ Million & 6 & 2 & 20 & 26 & 21 & 4 & 79 \\
\hline & c. 2 million- 4 million & 23 & 50 & 78 & 23 & 80 & 6 & 260 \\
\hline & d. $>4$ million & 1 & 39 & 4 & 3 & 7 & 3 & 57 \\
\hline \multirow[t]{3}{*}{6.} & Side job & & & & & & & \\
\hline & a. There is & 8 & 12 & 3 & 7 & 9 & 0 & 39 \\
\hline & b. There is no & 29 & 108 & 117 & 71 & 121 & 20 & 466 \\
\hline \multirow[t]{3}{*}{7.} & $\begin{array}{l}\text { Ownership of mining } \\
\text { land }\end{array}$ & & & & & & & \\
\hline & a. Land owner & 5 & 0 & 0 & 0 & 0 & 0 & 5 \\
\hline & b. Not owner & 32 & 0 & 0 & 0 & 0 & 0 & 32 \\
\hline
\end{tabular}

Source: Collected by the Author

*) Description: Grouping types of employment

1) Stone miner: Stone mining works as land owner and not land owner

2) Civil Servant: Civil servants, soldiers, police, retirees, honorary employees, bank employees, and salaried employees from government funding sources

3) Trader: Type of business that markets a product both large and small scale.

4) Farmer: Farming, gardening, breeders, fishermen, forest harvesters, etc.

5) Private Worker: Private company employees, independent private workers, etc.

6) Service: Driver, salon owner, barber, motorbike/electrical workshop, carpenter, mason, etc. 
Table 6.

Perceptions of the Community around the Bukit Tangkiling Conservation Area Per Job Type of Employment

\begin{tabular}{|c|c|c|c|c|c|c|c|c|}
\hline \multirow[b]{2}{*}{ No } & \multirow[b]{2}{*}{ Description } & \multicolumn{7}{|c|}{ Type of employment *) } \\
\hline & & $\begin{array}{l}\text { Stone Miner } \\
\text { (p) }\end{array}$ & $\begin{array}{c}\text { Civil } \\
\text { Servant } \\
\text { (p) }\end{array}$ & $\begin{array}{c}\text { Trader } \\
\text { (p) }\end{array}$ & $\begin{array}{l}\text { Farmer } \\
\quad(p)\end{array}$ & $\begin{array}{c}\text { Private } \\
\text { worker } \\
\text { (p) }\end{array}$ & $\begin{array}{l}\text { Services } \\
\text { (p) }\end{array}$ & $\begin{array}{c}\text { Total } \\
(p)\end{array}$ \\
\hline \multirow[t]{4}{*}{1.} & Forest Function & & & & & & & \\
\hline & a. Understand & 13 & 111 & 104 & 39 & 107 & 11 & 385 \\
\hline & b. Not really understand & 2 & 7 & 12 & 23 & 16 & 8 & 68 \\
\hline & c. Do not understand & 22 & 2 & 4 & 16 & 7 & 1 & 52 \\
\hline \multirow[t]{4}{*}{2.} & Conservation Area Function & & & & & & & \\
\hline & a. Understand & 10 & 108 & 104 & 49 & 97 & 15 & 383 \\
\hline & b. Not really understand & 2 & 5 & 14 & 15 & 11 & 2 & 49 \\
\hline & c. Do not understand & 25 & 7 & 2 & 14 & 22 & 3 & 73 \\
\hline \multirow[t]{4}{*}{3.} & $\begin{array}{l}\text { Existence of Conservation } \\
\text { Area }\end{array}$ & & & & & & & \\
\hline & a. Agree & 20 & 111 & 109 & 57 & 108 & 15 & 420 \\
\hline & b. Disagree & 3 & 1 & 2 & 0 & 1 & 1 & 8 \\
\hline & c. Do not know & 14 & 8 & 9 & 21 & 21 & 4 & 77 \\
\hline \multirow[t]{4}{*}{4.} & Existence of Stone Mine in C & Conservation & Irea & & & & & \\
\hline & a. Agree & 28 & 16 & 8 & 17 & 13 & 5 & 87 \\
\hline & b. Disagree & 2 & 98 & 107 & 50 & 100 & 13 & 370 \\
\hline & c. Do not know & 7 & 6 & 5 & 11 & 17 & 2 & 48 \\
\hline
\end{tabular}

Source: Collected by the author

City, Central Kalimantan Province. The data in Table 1 shows that land use for the two villages is divided into settlements, plantations, graves, yards, parks, offices, and other public infrastructure. Most of the land in the villages of Banturung and Tangkiling is intended to be used as settlements and other public infrastructure, namely $81.81 \%$ in Banturung Village and $94.01 \%$ in Tangkiling Village. This condition, with the least area allocated for community business land, has resulted in a tendency for the community to intervene in forest areas and conservation areas that are in their territory illegally to fulfill their daily needs.

The limited land owned by the community around the forest will result in the condition of the forest around it. They will depend on the forests around their settlements to meet the increasing needs of their lives. Without proper management, this is a threat to the existence and sustainability of the forest and can reduce the function of the forest designation (Senoaji, 2011, p. 2).

Economic potential exists in Banturung and Tangkiling villages, which can improve the standard of living and welfare of that community, including the Agriculture Sector, Plantation Sector, Ranch Sector, Fisheries Sector, and Mining and Excavation Sector. The income level of the residents of Banturung and Tangkiling, which are known for their large plantation and livestock sectors, have a value of 3,375,000 IDR for each plantation household, and 3,570,000 IDR for each farm household (BKSDA Kalimantan Tengah, 2017). Based on the data obtained as listed in Table 2, the mining and quarrying sector contributed significantly to improving the economy of the community in the Banturung and Tangkiling villages. The production value produced by the Banturung village is 510,000,000 IDR and the Tangkiling village is 59,000,000 IDR.

The data in Table 3, shows that the population in 2016 was 5,625 people 
in Banturung village and 2,919 people in Tangkiling village. Hastanti \& Triantoro (2012, p. 153) stated that the population that inhabits a region will affect the welfare of the community if it is associated with the amount of community income. The greater the population that inhabits an area, the greater the economic burden on that community. Especially if the majority of the productive-age population does not work or has no income. The amount of income of a community in an area will affect purchasing power, money turnover, and inflation rates in that area.

Most of the Bukit Tangkiling conservation areas are residential areas, where there are community groups that lived for quite a long time from 1990 with livelihoods mostly as farmers, traders, ranchers, gardeners, and stone miners (BKSDA Kalimantan Tengah, 2018:20). The data in Table 4 shows that, the population of the Banturung and Tangkiling villages is dominated by a productive age for work. Of the total population in each village, the population with the age group of $18-56$ years reached $59 \%$ in Banturung village and $54.97 \%$ in Tangkiling village.

Age has a relationship with one's responsibility for job offers; the more a person's age increases, the greater his/her job offer. So long as they are in their productive age, the higher the age of a person, the greater the responsibility to work. At a certain age, these responsibilities will decrease with age. Generally, someone who works will affect his socioeconomic conditions. (Febriana et al., 2016, p. 46).

Judging from the level of education, both villages are still dominated by people who have a low level of education. This can be seen in the data of the education level of the population below the senior high school, which is $72.96 \%$ in Banturung and $73.29 \%$ in Tangkiling.

Education is a basic effort to contribute human business abilities in order to advance activities. Education as an aspect that contributes human resources intended to increase one's knowledge and abilities in various activities, is also expected to be able to open up economic ways of thinking in terms of being able to develop existing potential to obtain maximum results (Basrowi \& Juariyah, 2010, p. 59).

The low level of education of the population in both villages has resulted in low competitiveness in finding and creating employment. This is reflected in the quite high number of those in Banturung who are unemployed, namely $14.99 \%$, when compared to the open unemployment rate of $4.82 \%$ (Central Kalimantan in Figures in 2017). Besides that, the number of residents who have unclear jobs is $26.74 \%$ in Banturung village and $43.85 \%$ in Tangkiling village. Sitompul and Situmorang (2010, pp. 87-88) stated that basically people who only complete elementary and junior high schools work as traders and laborers. Most of those who graduated from high school were private employees and entrepreneurs, while those who graduated with diplomas worked as teachers and civil servants.

The low competitiveness in finding and creating employment as a result of the low level of community education is an indication of one of the triggers of community intervention in the Bukit Tangkiling conservation area by carrying out rock mineral mining activities. This indication can be seen from the high production value of the mining and quarrying sector in the form of sand and stone commodities, amounting to nearly 510,000,000 IDR in Banturung and 59,000,000 IDR in Tangkiling (see Table 2).

Education is very important as an instrument for improving family welfare, because based on various literature on human resources, the effect of education on poverty is not limited to things related to money through income and wages, but also concerning aspects not related to money such as health, nutrition, housing, etc. (Zuluaga, 2005 as cited in Muflikhati et al., 2010, p. 6).

The population livelihoods of Banturung and Tangkiling villages are mostly farmers, 
ranchers, gardeners, and fishermen, whose numbers reach $21.71 \%$ in Banturung and $29.30 \%$ in Tangkiling. The people who have other livelihoods are army, police, and Government employees in Banturung village $4.96 \%$ and Tangkiling village $6.48 \%$; those retired in Banturung are $0.41 \%$, and in Tangkiling village $0.62 \%$; students in Banturung village is $15.64 \%$; private/self employed in Banturung village is $15.56 \%$, and in Tangkiling village $19.75 \%$. The number of people who have not worked and have unclear jobs (others) is quite high, namely in the Banturung Sub-District of $41.73 \%$ and in the Tangkiling Sub-District at $43.85 \%$. The number of people who have not worked and have unclear jobs is far above the unemployment rate of Central Kalimantan in 2016, which is $4.82 \%$ (BPS Central Kalimantan, 2017).

Sitompul and Situmorang (2010, p. 87) stated that livelihood determines the size of income in a family, which in turn will affect the level of welfare of the community.

If someone has a low level of education, it will affect the socio-economic conditions of a society. With such low education conditions, there will be a lot of unemployment in the community. Unemployment is generally caused by the number of workforce or job seekers is not proportional to the number of jobs available. Unemployment often creates a problem in the economy, because with unemployment, the productivity and income of the people will decrease, so that it can cause poverty and other social problems (Basrowi\&Juariyah, 2010, p. 66).

The harmonious life between the religious community in Banturung and Tangkiling Village is quite well maintained. Although the inhabitants adhere to different religions, but there has never been a conflict between religious communities, even between religious communities that exist, mutual support and mutual assistance in living their daily lives. In Banturung and Tangkiling village, the majority of the population is Muslim, namely: in Banturung $66.04 \%$ and in Tangkiling $48.57 \%$. Furthermore, the population of Christians in Banturung is $30.35 \%$ and Tangkiling is $37.40 \%$. There are also residents who are Hindus in Banturung (2.45\%) and Tangkiling (10.65\%). In this case, it is the Hindu Kaharingan religion, which is the original religion inherited from the Dayak tribe ancestors in Central Kalimantan Province. The rest, namely other residents who are Catholic, Buddhist, or hold other beliefs are as much as $1.15 \%$ in Banturung village and $3.38 \%$ in Tangkiling village. Hastanti and Triantoro (2012, p. 154), state that religion also plays a role and influences the governance of people's lives.

\section{Household Conditions around the Bukit Tangkiling Conservation Area}

Based on data on the existence and condition of households in Table 5, the majority of people living around the Bukit Tangkiling conservation area work as entrepreneurs; namely, private workers, traders, farmers, stone miners, as well as civil servants. It can be seen, respectively, that household heads have livelihoods as private workers $(25.74 \%)$, traders $(23.76 \%)$, civil servants $(23.76) \%)$, farmers $(15.45 \%)$, stone miners $(7.33 \%)$, and other fields (3.96\%). Senoaji (2011) states that the type of work of the population will be closely related to community pressure into the forest.

The number of villagers who are working in agriculture tends to increase the confessional value of the pressure of their population into forest areas; this is due to the limited agricultural land due to population growth (Senoaji \& Ridwan, 2006, as cited in Senoaji, 2011, p. 8).

The composition of the percentage of the population around the Bukit Tangkiling conservation area is based on the classification of types of work, as in Figure 1.

The community around the Bukit Tangkiling conservation area is dominated by the heads of 
Figure 1.

Percentage of the population residing around the Bukit Tangkiling conservation area based on the type of employment

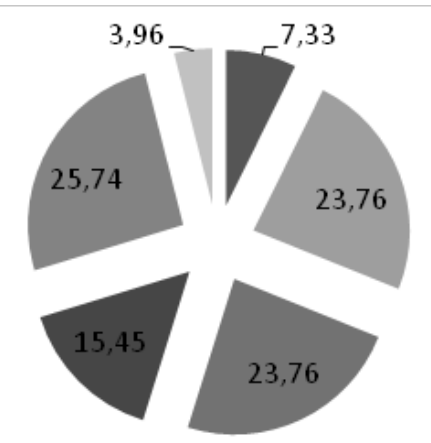

$\square$ Stone miner

- Civil servant

- Trader

- Farmer

Private Worker

Service

Source: Collected by the author

the family with the age group 18 to 56 years $(79,00 \%)$, which is a productive age group for employment. For the level of education, it was dominated by high school and university graduates as much as $66.93 \%$, and compared with the junior high school education level below as much as $33.07 \%$. As for the level of income, the level of income is 2,000,000 IDR to 4,000,000 IDR per month or higher, which is $62.77 \%$. In terms of the level of income, it can be said that most of the people around the Bukit Tangkiling conservation area have quite prosperous households. This is to say, when compared with the Central Kalimantan Province Minimum Wage in 2018 of 2,421,305 IDR (based on: Governor of Central Kalimantan Decree No. 37/2017 concerning Minimum Wages and Provincial Sectoral Minimum Wages of 2018 Central Kalimantan Province), and Central Kalimantan Poverty Line Number in 2016 of 380,524 IDR per month per person (Central Kalimantan Province BPS: Central Kalimantan Province 2017 in Numbers).

Based on the results of the analysis of the obtained data, the heads of the family who have a job as a stone miner predominantly have a low level of education (junior high school and lower), which is $70.27 \%$, making it the highest percentage of other types of employment groups. The low level of education of most of the stone miners is due to the fact that working as a stone miner does not require skills that demand a high level of education. In addition, from the data on the ownership status of the land, most of the stone miners are not land owners $(86.49 \%)$, only laborers.

Communities that have a low socioeconomic level tend to have low levels of education. The community still does not understand the importance of education. The community still thinks that education is not a guarantee of prosperous life, far from poverty; assuming that schools only waste time and money. Basic education alone is not enough to support ongoing development, as there are still many people who have not succeeded in completing basic education to completion (Basrowi \& Juariyah, 2010, p. 59).

It is undeniable, for family heads who have a low level of education, that work as a stone miner is a very promising alternative job, considering the competitiveness of the community is very low, to find and create decent jobs. Looking at the monthly income data, stone mine workers who have a monthly income of 2,000,000 IDR up to 4,000,000 IDR reached a percentage of $64.86 \%$. This is an illustration that the type of livelihood as a stone miner is able to increase household and community income, especially for those who have a low level of education with low competitiveness in finding and creating decent employment.

An interesting takeaway is that income is not a significant factor in its influence on welfare with all indicators. This shows that, despite an important increase in income, it is not enough to improve family welfare without being accompanied by changes in the mindset and behavior of the community, especially in investing in human resources such as education and health (Muflikhati et al., 2010, p. 6).

Stone miners who work in the Bukit Tangkiling conservation area are mostly nonindigenous people who have traditionally lived in the area as much as $75.67 \%$, and are also not landowners as much as $86.49 \%$. Stone miners 
are menial workers who only take wages for work provided by landowners.

BKSDA Kalimantan Tengah (2018) revealed data stating that most of the people living in the Bukit Tangkiling conservation area had ownership of their land in the form of a Land Declaration and Ownership Certificate. It is recorded that there are 39 ownership of land certificates within the area.

The existence and socio-economic conditions of the household with the type of work as a stone miner can be seen in Figure 2.

Public perception of the existence of the Bukit Tangkiling conservation area and the existence of rock mining in the Bukit Tangkiling conservation area

The socio-economic existence and conditions of household communities around the Bukit Tangkiling conservation area are inseparable from how the community itself perceives the existence and function of the Bukit Tangkiling conservation area. The community's perception and understanding about the importance of the existence of the Bukit Tangkiling conservation area will affect the community intervention in the area, which in turn will affect the environmental conditions.

Community development efforts in the buffer zone of Bukit Tangkiling conservation area are a demand to protect the area from various disturbances originating from outside or within the region, which have the potential to damage or change the integrity of the regional functions. The government needs to involve the community through community empowerment (BKSDA Kalimantan Tengah, 2018 , p. 2). In line with this, Dian \& Hapsari (2012) stated that increasing public awareness in managing an area is very important for the success of the area's management efforts (Nanlohy et al., 2014, p. 90).

Figure 2.

The existence and socio-economic conditions of the household with work as a stone miner

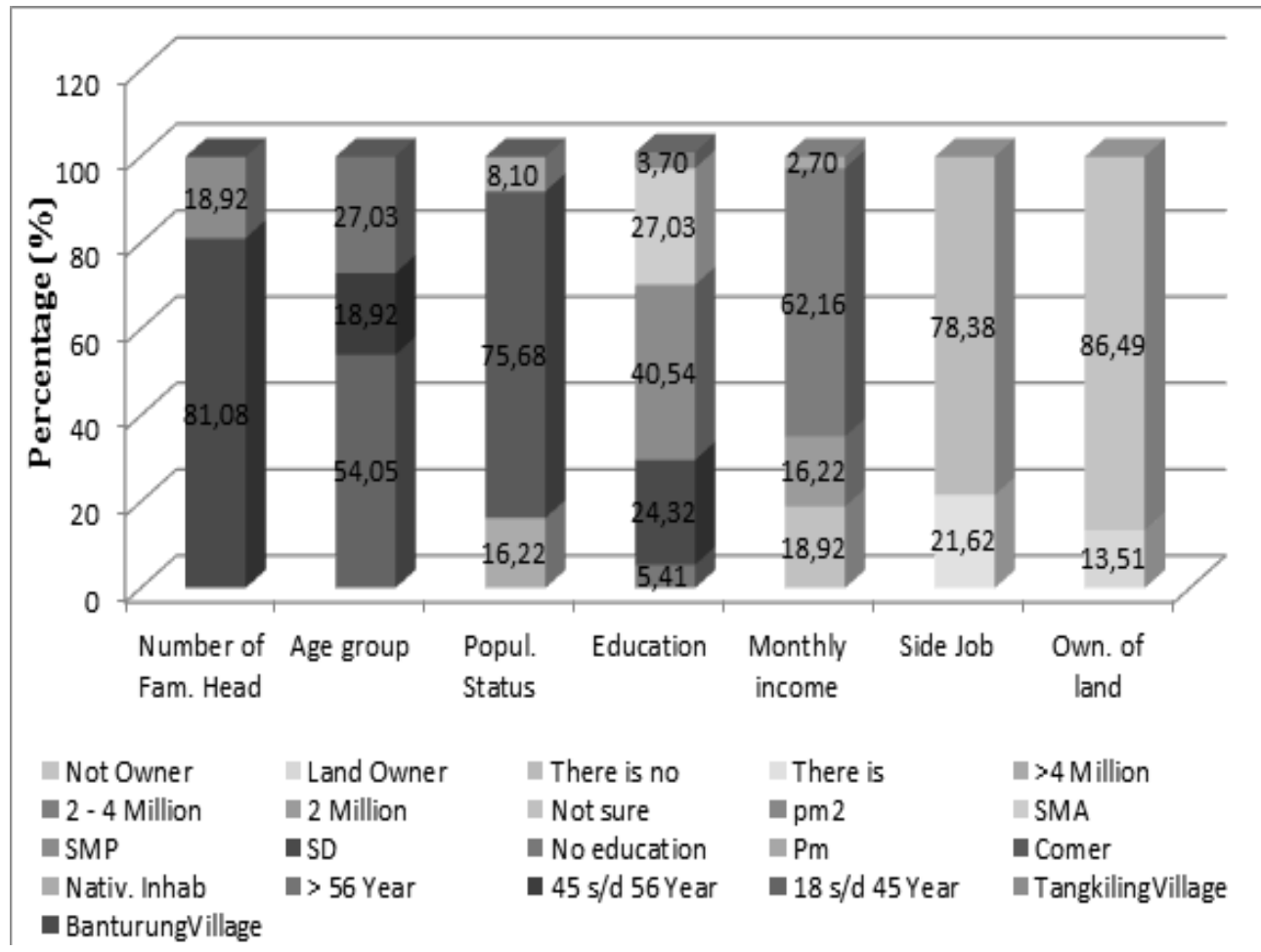

Source: Collected by the author 
Figure 3.

Perceptions of stone miners on the existence of the Bukit Tangkiling conservation area and the existence of rock mineral mining activities in the Bukit Tangkiling conservation area.

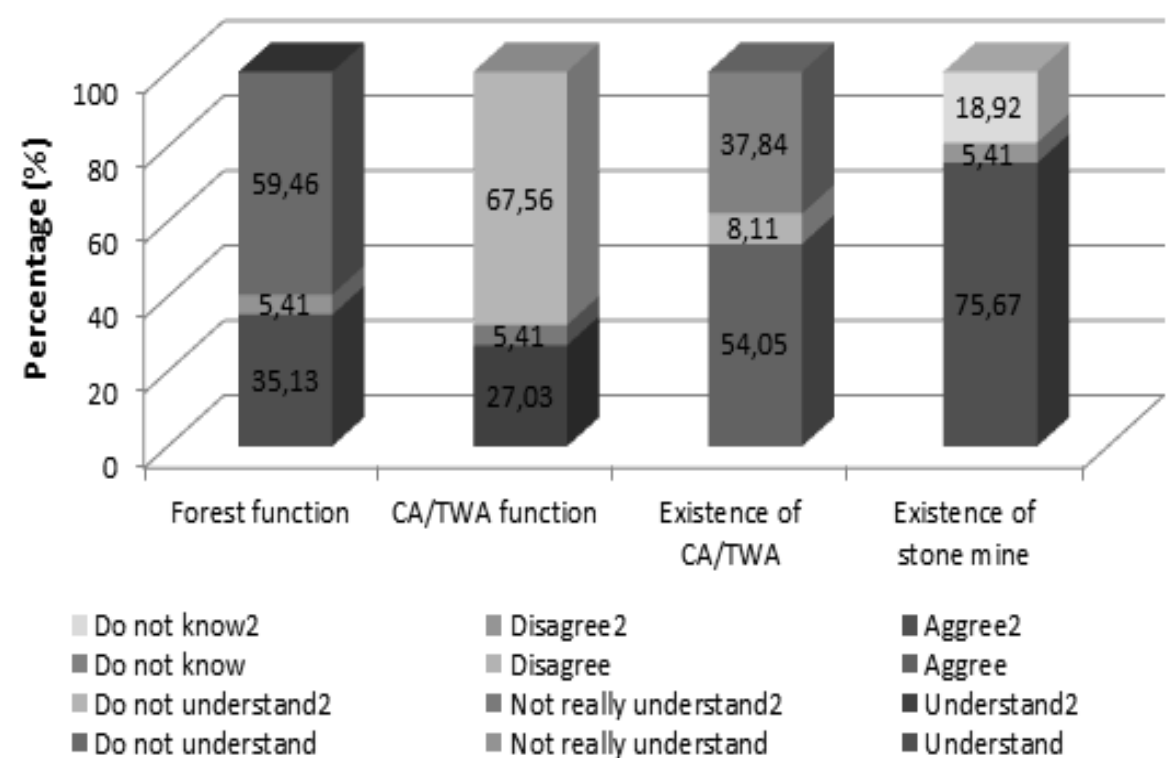

Source: Collected by the author

Based on the data in Table 6, which is a description of the perception of the community around the Bukit Tangkiling conservation area based on the type of work they have, most of the people that work as rock miners with a low level of education do not understand the function of the forest or the functions of the Bukit Tangkiling conservation area. It can be seen that stone miners who do not understand the function of the forest are $64.86 \%$, and miners who do not understand the functions of the conservation area are $72.97 \%$. This condition generally makes stone miners apathetic toward the existence of the Bukit Tangkiling conservation area as areas that must be maintained and preserved. This condition is illustrated by $45.99 \%$ of stone miners who argue that they do not know and do not agree with the existence of the Bukit Tangkiling conservation area. In addition, most stone miners $(75.67 \%)$ agree with the presence of rock mineral mining activities in the Bukit Tangkiling conservation area. This is in line with the statement of Hastanti and Triantoro (2012, p. 154), that the low level of education of the community causes a lack of understanding of the meaning of conservation of natural resources in the future. In addition, with relatively low education and lack of skills, many people hope for the existence of employment, without understanding the negative ecological impacts on the lives of future generations.

The perceptions of the stone miners are inversely proportional to other types of employment, such as civil servants, traders, farmers, and private workers, who have the most understanding of the functions of forest and function of the Bukit Tangkiling conservation area, and approve of its existence. They also do not approve of the existence of rock mineral mining activities in the Bukit Tangkiling conservation area. The perception of the stone mine workers in the presence of 
the Bukit Tangkiling conservation area and the existence of rock mineral mining activities in the Bukit Tangkiling conservation area can be seen in Figure 3.

\section{Conclusions}

The population of Banturung and Tangkiling Villages is dominated by a productive age for workers, with the age group of 18 - 56 years reaching $59.00 \%$ in Banturung Village and $54.97 \%$ in Tangkiling Village. Judging from the level of education, the two villages have a low level of education. This can be seen in the data of the education level of the population below the senior high school, which is $72.96 \%$ in Banturung village and $73.29 \%$ in Tangkiling village. The highest number of population livelihoods is farmers/ ranchers/gardeners/fishermen; the number reaches $21.71 \%$ in Banturung and 29.30\% in Tangkiling. Residents who have not worked and have unclear jobs (others) are quite high, namely in the Banturung Sub-District of $41.73 \%$ and in the Tangkiling Sub-District at $43.85 \%$.

Harmonious life between the religious communities in Banturung and Tangkiling Village is quite well maintained and has a fairly high tolerance among religious communities. There has never been a conflict between the religious communities. The majority of the population is Muslim, then followed by Christians, Hindu Kaharingan, Catholics, Buddhists, and other beliefs.

The low level of education owned by the people of Banturung and Tangkiling makes the ability to compete for jobs and create jobs very low, making it difficult for people to find decent work. The condition of the low competitiveness in finding and creating employment has made the community look for other employment alternatives that fit their needs and abilities. Work as a stone miner is the most likely alternative choice for people who have a low level of education, because it does not require expertise and skills that require such. From the research data obtained, the work of mining this stone can improve the household economy of the community, where $64.84 \%$ of stone miners have an income of 2-4 million rupiahs per month.

Stone miners with a low level of education do not understand the function of the forest or the functions of the Bukit Tangkiling conservation area. This condition makes the stone miners tend to be apathetic toward the existence of the Bukit Tangkiling conservation area as areas that must be maintained and preserved. This is inversely proportional to other types of occupations that require a higher level of education.

The right strategy is needed to properly manage and utilize the Bukit Tangkiling conservation area, which can accommodate all existing interests, and can suppress the occurrence of conflict, so that conflicts can be overcome and prevented without overriding the main function of the conservation area itself.

To be able to increase public understanding of the existence of Bukit Tangkiling conservation area, as well as improve the economy of community households, socialization activities are needed on the importance of the functions of forests and conservation areas. In addition, it is also necessary to hold skills-improvement and independent-business training activities for the community around the Bukit Tangkiling conservation area.

\section{References}

BPS Kalimantan Tengah. (2017). Provinsi Kalimantan Tengah dalam angka Tahun 2017. Palangka Raya. Palangka Raya: BPS Kalimantan Tengah.

BKSDA Kalimantan Tengah. (2017). Laporan pelaksanaan kegiatan pengumpulan data dalam rangka pengusulan evaluasi fungsi kawasan hutan CA/TWA Bukit Tangkiling. Palangka Raya: BKSDA Kalteng.

BKSDA Kalimantan Tengah. (2018). Laporan kegiatan identifikasi hak-hak masyarakat 
di kawasan CA/TWA Bukit Tangkiling. Palangka Raya: BKSDA Kalteng.

BKSDA Kalimantan Tengah. (2018). Laporan Pengumpulan Data Sosial dan Ekonomi Kelurahan Tangkiling Kota Palangka Raya. Palangka Raya: BKSDA Kalteng.

Basrowi, \& Juariyah, S. (2010). Analisis kondisi sosial ekonomi dan tingkat pendidikan masyarakat Desa Srigading, Kecamatan Labuhan Maringgai, Kabupaten Lampung Timur. Jurnal Ekonomi dan Pendidikan, 7(1), 58-81. doi: 10.21831/jep.v7i1.577

Febriana, L., Normelani, E., \& Hastuti, K. P. (2016). Identifikasi Kondisi Sosial Ekonomi Penduduk di Kelurahan Kelayan Luar Kecamatan Banjarmasin Tengah. JPG (Jurnal Pendidikan Geografi), 3(2), 42-50. doi: 10.20527/jpg.v3i2.1462

Gubernur Kalimantan Tengah. (2017, November 1). Surat Keputusan Gubernur Kalimantan Tengah Nomor: 37 tahun 2017 tentang Upah Minimum dan Upah Minimum Sektoral Provinsi Tahun 2018 Provinsi Kalimantan Tengah. Palangka Raya: Pemerintah Provinsi Kalimantan Tengah.

Hastanti, B. W., \& Triantoro, R. G. N. (2012). Kondisi Sosial Ekonomi dan Budaya Masyarakat Sekitar Kawasan Konservasi: Studi Kasus di Pulau GAG, Raja Ampat, Papua Barat (Social Economic and Culture Conditions of Community Around Conservation Area: Case Study at Gag Island, Raja Ampat, West Papua). Jurnal Penelitian Kehutanan Wallacea, 1(2), 149-164. doi: 10.18330/jwallacea.2012. vol1iss2pp149-164

Kelurahan Banturung. (2016). Profil Kelurahan Banturung. Palangka Raya: Pemerintah Kota Palangka Raya.

Kelurahan Tangkiling. (2016). Profil Kelurahan Tangkiling. Palangka Raya: Pemerintah Kota Palangka Raya.
Menteri Pertanian Republik Indonesia. (1977, 25 January). Keputusan Menteri Pertanian Republik Indonesia Nomor:46/Kpts/Um/1/1977 tentang Penunjukan Areal Hutan Bukit Tangkiling Dan Sekitarnya Seluas 2.594 ha Yang Terletak di Kotamadya Palangka Raya Sebagai Kawasan Hutan Dengan Fungsi Sebagian Seluas 2.061 ha sebagai Suaka Alam / Cagar Alam dan Sebagian Lagi Seluas 533 ha Sebagai Hutan Wisata / Taman Wisata. Jakarta: Departemen Pertanian Republik Indonesia. Muflikhati, I., Haryoto., Sumarwan, U., Fahrudin, A., \& Puspitawati, H. (2010). Kondisi sosial ekonomi dan tingkat kesejahteraan keluarga: Kasus di wilayah Pesisir Jawa Barat. Jurnal Ilmiah Keluarga dan Konsumen, 3(1), 1-10. doi: 10.24156/ jikk.2010.3.1.1

Nanlohy, H., Bambang, A. N., Ambaryanto., \& Hutabarat, S. (2014). Analisis Persepsi Masyarakat Terhadap Pengelolaan Kawasan Mangrove Teluk Kotania. Jurnal Wilayah dan Lingkungan, 2(1), 89-98. doi: 10.14710/jwl.2.1.89-98

Pramusita, A., \& Sarinastiti, A. N. (2018). Aspek sosial ekonomi masyarakat lokal dalam pengelolaan Desa Wisata Pantai Trisik, Kulonprogo. Jurnal Pariwisata Terapan, 2(1), 14-25. doi: 10.22146/jpt.35378

Senoaji, G. (2011). Kondisi sosial ekonomi masyarakat sekitar hutan lindung bukit daun di Benkulu. Jurnal Sosiohumaniora, 13(1), 1-17. doi: 10.24198/sosiohumaniora. v13i1.5458

Sitompul, M., \& Situmorang, R. (2010). Keadaan Sosial Ekonomi di Desa Terpencil Kecamatan Stabat. Jurnal Geografi, 2(2), 81-92. doi: 10.24114/jg.v2i2.6372

Sugiyono. (2017). Metode penelitian kebijakan: Pendekatan kuantitatif, kualitatif, kombinasi, $R \in \mathcal{E} D$ dan penelitian evaluasi. Bandung: Penerbit Alfabeta. 